Terr. Atmos. Ocean. Sci., Vol. 18, No. 2, 243-269, June 2007

\title{
Characteristics of the Lithology, Fault-Related Rocks and Fault Zone Structures in TCDP Hole-A
}

\author{
Sheng-Rong Song ${ }^{1, *}$, Li-Wei Kuo ${ }^{1}$, En-Chao Yeh $^{1,2}$, Chien-Ying Wang ${ }^{3}$, \\ Jih-Hao Hung ${ }^{3}$, and Kuo-Fong $\mathrm{Ma}^{3}$
}

(Manuscript received 18 January 2006, in final form 15 January 2007)

\begin{abstract}
The main objective of the Taiwan Chelungpu-fault Drilling Project (TCDP) was to conduct an in-depth probe into a fault zone of recent major activity so as to gain a better understanding of and more insight into the physical, mechanical and chemical properties involved. By the end of 2004, with the completion of the drilling of Hole-A, cuttings from 0 to $431.34 \mathrm{~m}$ and cores from a 431.34- to 2003.26-m depth had been obtained. Stratigraphically, the Pliocene to Pleistocene Cholan Formation is found from the surface to a 1029-m depth and is predominantly composed of sandstone and sandstone-siltstone alternations with weak to intense bioturbation. The Pliocene Chinshui Formation is observed from a depth of 1029- to 1303-m and predominantly consists of siltstone with weak bioturbation. From 1303- to 1712-m down there is the late Miocene to early Pliocene Kueichulin Formation which is predominantly composed of massive sandstone with minor siltstone. Below $1712 \mathrm{~m}$, the Formation again resembles the younger Cholan Formation with mollusca-rich, thick, layered shale and heavy bioturbated sandstone. Four types of fault-related rocks are identified in the cores. They are the fault breccia, gouges, foliated and non-foliated cataclasites and pseudotachylytes. At least six major fault zones are
\end{abstract}

\footnotetext{
${ }^{1}$ Department of Geosciences, National Taiwan University, Taipei, Taiwan, ROC

2 Kochi Institute for Core Sample Research, Japan Agency for Marine-Earth Science and Technology, Kochi, Japan

${ }^{3}$ Department of Earth Sciences and Institute of Geophysics, National Central University, Chung-Li, Taiwan, ROC

* Corresponding author address: Prof. Sheng-Rong Song, Department of Geosciences, National Taiwan University, Taipei, Taiwan, ROC; E-mail: srsong@ntu.edu.tw doi: 10.3319/TAO.2007.18.2.243(TCDP)
} 
found in the cores: FZ1111, FZ1153, FZ1220, FZ1580, FZ1712, and FZ1812. Among these, FZ1111 most probably corresponds to the slip surface of the Chi-Chi earthquake, the Chelungpu fault, while FZ1712 very likely represents the Sanyi fault.

\author{
(Key words: Taiwan Chelungpu-fault Drilling Project, Fault zone architecture, \\ Fault-related rocks, Chinshui Formation)
}

\title{
1. INTRODUCTION
}

The highly destructive 1999 Chi-Chi earthquake $\left(M_{w}=7.6\right)$ struck near the town of Chi-Chi in Nantou County, west-central Taiwan (Fig. 1), with its epicenter about $15 \mathrm{~km}$ east of the surface trace of the thrust fault at $120.82^{\circ} \mathrm{E}$ and $23.85^{\circ} \mathrm{N}$ and a hypocenter depth of about 10 - $12 \mathrm{~km}$ (Ma et al. 1999; Kao and Chen 2000). It caused a total surface rupture of about $80-90 \mathrm{~km}$ along the Chelungpu fault and large vertical offsets reaching as high as $9 \mathrm{~m}$. As one of the largest inland events in the past century, it resulted in the death of about 2400, injured another 10000 and destroyed more than 100000 buildings.

Apart from the spectacular surface faulting that it produced, the 1999 Chi-Chi, Taiwan earthquake had unique rupture behavior that was well recorded by the Taiwan Strong Motion Network ( 600 stations) and GPS (130 stations). Using the strong motion data, teleseismic data and GPS displacement, several groups of researchers have proposed various models of the spatial distribution of slip and slip velocity of the earthquake. One general consensus that has emerged is that the slip occurred over an area of about 80 by $40 \mathrm{~km}$, with the hypocenter in the southern region and rupture propagation mainly toward the north (Johnson et al. 2001; Pathier et al. 2003; Yu et al. 2003). The inverted slip distribution correlates very well with the geological observations. The slip distribution shows most of the co-seismic slips occurred at depths of less than $10 \mathrm{~km}$, and a large slip of up to $12 \mathrm{~m}$ has been reported in shallow depths at the northern end of the fault (Ma et al. 2003).

Central to understanding a particular earthquake rupture process is knowing the level of stress change on the fault caused by the earthquake. The balance of energy from tectonic stress, dynamic friction, radiated energy and heat dissipation controls the character of the dynamic rupture. True that many hypotheses have been put forth to explain how a fault loses strength during sliding, including slip weakening, dilatational slip pulses, thermal pressurization, mechanical lubrication and melting, yet to make even greater strides in understanding how large earthquakes occur, it is critical to have sufficient physical and chemical data as well (Chester and Chester 1998; Kanamori et al. 1998; Kanamori and Heaton 2000). The upcoming results from the Taiwan-Chelungpu Drilling Project (TCDP) will surely help sedimentologists not to mention field and tectonic structural geologists alike to fulfill such requirements. The specific purpose of the TCDP has, in fact, been to obtain physical samples along the fault where large displacements occurred during the Chi-Chi earthquake. Physical and chemical observations of the fault zone should make it much more possible to better determine such salient features as the dynamic frictional characteristics of the fault. The large number of slips at or near the fault surface provides a unique opportunity to study first-hand the physical 


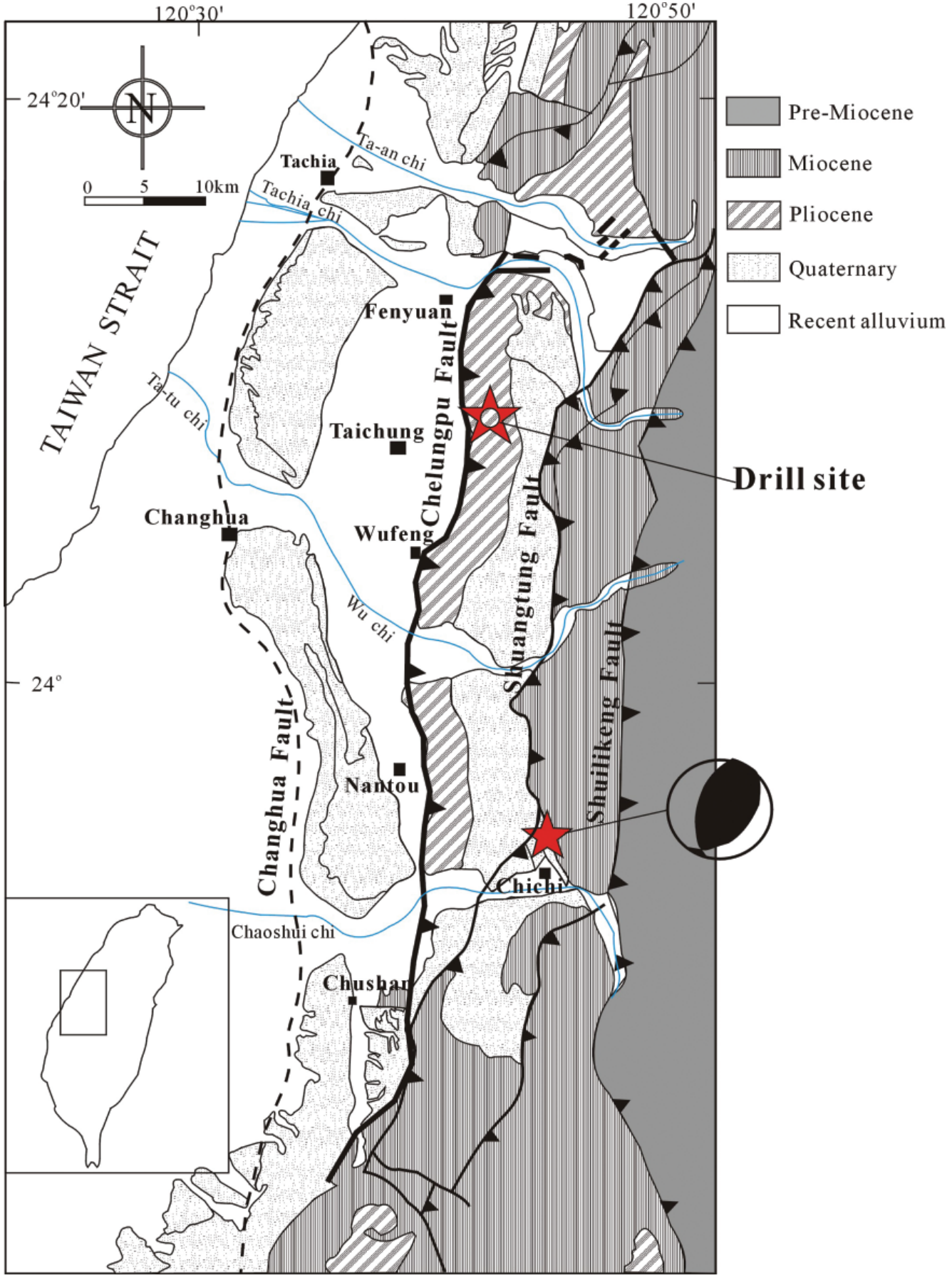

Fig. 1. Geological map showing the extent of the 1999 Chelungpu-fault surface rupture and the TCDP drill site. Map modified from Chen et al. (2003). 
mechanisms and chemical reactions involved in this massive earthquake faulting. The behavior of the thrust fault system of the Chelungpu fault around the time of the 1999 Chi-Chi earthquake presents ideal conditions for seismogenetic analyses in that the fault zone is characterized by shallow dipping, which is highly amenable to imaging and drilling. With this in mind, the NSC granted the TCDP funding in 2003, thereby allowing for the drilling of deep holes into the Chelungpu fault zone so as to obtain samples to shed light on the aforementioned issues. Begun in January 2004, the drilling of Hole-A was completed to the depth of $2003.26 \mathrm{~m}$ by the end of 2004 . The upper $431 \mathrm{~m}$ was drilled with a rotary, but no core samples were taken. Drilling from 431 to $500 \mathrm{~m}$ had the purpose of testing the coring, while that from 500 to $2003 \mathrm{~m}$ was entirely for coring. This paper presents first-hand data on the lithology, stratigraphy, fault zone rocks and structures that have been obtained from this project.

\section{GEOLOGICAL SETTING}

Taiwan is located within the complexity of the oblique collision zone of the Eurasian continental plate and the Philippine Sea plate which (Fig. 1) is moving WNW at about $70 \mathrm{~mm}$ per year (Seno and Maruyama 1984). It is now widely believed that the mountain-building process is still in progress (Tsai et al. 1981; Yu and Chen 1994; Yu et al. 1999) and that a dominant collision zone that frequently induces folding and fault thrusting, much like the Chelungpu thrust fault, probably exists in west-central Taiwan. At the latitude of southern Taiwan, the Philippine Sea plate is riding up over the continental shelf of the South China Sea. Such active movements over the last 10 million years have been creating the island of Taiwan (Ho 1986; Teng 1987, 1990). More recently, in the last few hundred years, rapid crustal movement and widely distributed active structures have induced at least tens of large earthquakes with magnitudes of over 7.0 (Yu et al. 1997, 1999).

Structurally, the Western Foothills of Taiwan are characterized by a series of subparallel thrust faults. Also common in the foothills are fault-bend and fault propagation fold structures, with the thrust they form a west-verging fold-thrust belt (Suppe 1981). The age of the foldthrust activity in the Western Foothills is older in the north and progressively gets younger toward the south of Taiwan. A series of east-dipping reverse faults from the east to the west, namely the Shuichangliu, Shuangtung, Sanyi-Chelungpu and the Changhua faults, is distributed in this area (Fig. 1). The Chi-Chi earthquake of September 21, 1999 was triggered by the movement of the Sanyi-Chelungpu fault, which is thrusting Pliocene-Pleistocene strata over modern terrace sediments of the Taichung piggyback basin (Fig. 1).

The TCDP drilling site is located in the Takung area northeast of Taichung city (Fig. 1). Based on field mapping (Chen et al. 2003) and seismic reflection profiles (Hung and Wiltschko 1993; Hung and Suppe 2000), three sub-parallel thrust faults, the Sanyi and Chelungpu faults, occurred in the area of the TCDP drilling site. At depths, these east-dipping reverse faults merge with the Chelungpu fault in the south (Chen et al. 2003). Of these two faults, the Sanyi fault is the oldest in this area where the Miocene Tungkang Formation thrusts upward to the Pleistocene Toukoshan strata (Meng 1963). The Chelungpu fault produced 5- to 9-m vertical surface ruptures during the Chi-Chi earthquake, caused the Pliocene Chinshui and Cholan Formations as the hanging wall to move upward to the footwall which included 3-km-thick 
Toukoshan gravel that form the Taichung piggyback basin with relatively flat structural layers (Chang 1971).

Stratigraphically, several lithologic units were defined around the drilling site, from the youngest to the oldest: the Pleistocene Toukoshan Formation (partial or unconsolidated gravel), the Pleistocene to late Pliocene Cholan Formation (sandstone predominant with siltstone-sandstone alternations), the early Pliocene Chinshui Formation (mudstone predominant) and the early Pliocene to the late Miocene Kueichulin Formation (alternating sandstone and mudstone) (Ho 1986).

\section{DESCRIPTION OF THE CORES}

From the surface to a depth of $431.34 \mathrm{~m}$, no cores were taken; only cuttings were collected at the rate of one sample per $10 \mathrm{~m}$. Whole coring was carried out between 431.34 and $2003.26 \mathrm{~m}$ down, and at the same time, on-line gas monitoring was deployed throughout. Core recovery with cores $82 \mathrm{~mm}$ in diameter was good at over 97\%, except in the case of soft, unconsolidated sandstone in the 1700- to 1800 -m depth interval.

Once the cores were taken from the well, their length and depth were marked and registered. They were then photographed and cut into 1-m long segments to fit the carrying box. After this they were washed to remove the drill mud stuck to the surface. To obtain high resolution images, slabbing and unrolled scanning were performed with a Camera Image Scanner SmartCIS 1000. Detailed descriptions of the lithology, sedimentary features and the meso- and microstructures were done, and the data were keyed into the data information system of the International Continental Scientific Drilling Program (ICDP) (http://www.icdp-online.de/sites/ chelungpu/news/news.html). Before the cores were packed in a wooden box, some definitive intervals were sampled for the study of the geomicrobiology and anelastic strain recovery (ASR), as well as for the thermal property and gas-extraction measurements on site.

\subsection{Lithology and Stratigraphy}

The cuttings, i.e., rocks fully comminuted with drill bits in the upper $431.34 \mathrm{~m}$, are predominantly composed of sandstone chips with minor siltstone fragments. From 431.34 to $2003.26 \mathrm{~m}$ down, sandstone and siltstone predominate with minor mudstone and shale. The detailed description of the lithologic column, the sedimentary features, fault-related rocks, fracture density and structures are shown in Fig. 2. On the basis of surface geological mapping (Ho and Chen 2000), microfossils (Wu et al. 2007), and lithologically sequential variations, the cores are distinctly identified as being part of the Cholan, Chinshui, Kueichulin and Cholan Formations down-hole.

\subsubsection{Cholan Formation (I)}

Given that the cores from 431.34 to $1029 \mathrm{~m}$ at depth are characterized by thick sandstone and alternating sandstone-siltstone-mudstone layers with weak to intense bioturbations, it is the late Pliocene to the early Pleistocene Cholan Formation (Fig. 2). The thick sandstones are 
greenish-gray to light-gray, massive to well-laminated and fine- to coarse-grained. The thickness ranges from a few to over 20 meters. Bioturbations with abundant trace fossils, i.e., Skoliths and Zoophycus ichnofacies, are commonly found in the sandstone sequences. Distinct sedimentary structures, such as cross-, parallel-, flaser-, wave-, graded-, and contorted-beddings, transported shell fragments and highly carbonaceous materials are also distributed abundantly in this Formation. The alternating sandstone-siltstone-mudstone layers are characterized by alternations of thin and well-laminated layers of light sand and dark silt along with clay of weak bioturbated features. Several coarsening-upward assemblage cycles are the major lithofacies in this interval (Fig. 2). For the most part, this interval consists of rare fossils and abundant Miocene secondary reworked fossils, Sphenolithus abies Deflandre; however, the absence of Pleistocene to Holocene index nannofossils, Gephyrcapsa oceanica Kamptner (Wu et al. 2007) suggests that the stratigraphy belongs to the upper Pliocene. Petrographically, the sandstone is predominantly composed of quartz and slate fragments with subsidiary amounts of feldspar, sandstone, quartzite fragments, and clayed matrix. On account of these sedimentary structures and fragment compositions, it is concluded that the Cholan Formation was deposited in a delta environment.

\subsubsection{Chinshui Formation}

The depth interval from 1029 to $1303 \mathrm{~m}$ is the Pliocene to the early Pleistocene Chinshui Formation, and it is conformably overlain with the Cholan Formation. The boundary between them demarcates the first appearance of thick dark siltstone about $10 \mathrm{~m}$ immediately beneath thick sandstone with intensive bioturbation (Fig. 2). The Chinshui Formation is predominantly composed of siltstone with subsidiary thin layers of fine-grained sandstone, mudstone and alternating layers of sandstone and siltstone. The siltstone is a dark gray massive sequence with thin hummocky cross-bedded and moderate to intense bioturbated layers of fine sandstone. About a 10-m thick layer of fine sandstone at around $1210 \mathrm{~m}$ down is light gray and massive with intense bioturbations and trace fossils. The lithology of the sedimentary structures indicates that the Chinshui was deposited in shallow marine and intercalated tidal environments. The NN15 and NN12 - 14 nannofossil zones are respectively found in the depth interval of $1120 \sim 1201.5 \mathrm{~m}$ and $1267 \sim 1298 \mathrm{~m}$ (Wu et al. 2007), which indicates that the Chinshui Formation in the core is early to late Pliocene in age. It is worth noting that highly dense fractures, slip zones, and fault-related observations are widely distributed in this Formation, indicating definitely that the Chelungpu fault lies in this interval.

\subsubsection{Kueichulin Formation}

The Kueichulin Formation is found at 1303 to 1712 m down. Separated from the overlying Chinshui Formation by the last disappearance of thick relatively fine siltstone, it precedes down-hole with thick massive sandstone (Fig. 2). The Kueichulin Formation is late Miocene to Pliocene in age, and it is predominantly composed of light gray, thick, massive sandstone with subsidiary thin layers of siltstone and shale. The sandstone between the depths of 1400 and $1600 \mathrm{~m}$ is composed of coarse-grained, less consolidated sand. Based on the evidence 


\begin{tabular}{|c|c|c|c|c|c|c|c|c|}
\hline Formation & Depth & Lithology & \multicolumn{3}{|c|}{$\begin{array}{c}\begin{array}{c}\text { Sedimentary } \\
\text { Structures }\end{array} \\
\end{array}$} & \begin{tabular}{|c|}
$\begin{array}{c}\text { Fault-related } \\
\text { Rocks }\end{array}$ \\
\end{tabular} & Veins & \begin{tabular}{|c|}
$\begin{array}{c}\text { Fracture } \\
\text { Density (N) }\end{array}$ \\
\end{tabular} \\
\hline \multicolumn{3}{|c|}{$\begin{array}{l}\text { Shale } \\
\text { Siltstone } \\
\text { Siltstone with sands }\end{array}$} & \multicolumn{4}{|c|}{$\begin{array}{l}=\text { :Parallel lamination } \boldsymbol{\imath} \text { :Slight bioturbation } \\
\simeq \text { :Cross bedding } \quad \mathbb{Z} \text { :Intense bioturbation } \\
\underline{\text { c }}: \text { :ontorted bedding } \Psi: \text { Fossil } \\
\simeq \text { :Wave bedding } \quad \xi: \text { Trace fossil } \\
\end{array}$} & \multicolumn{2}{|c|}{ 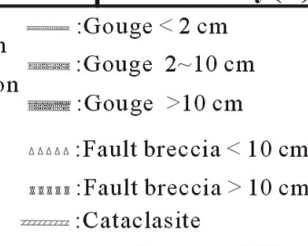 } \\
\hline 高 & $\begin{array}{l}430 \\
440- \\
450- \\
460- \\
470- \\
480- \\
490- \\
500- \\
510- \\
520- \\
560- \\
560-\end{array}$ & 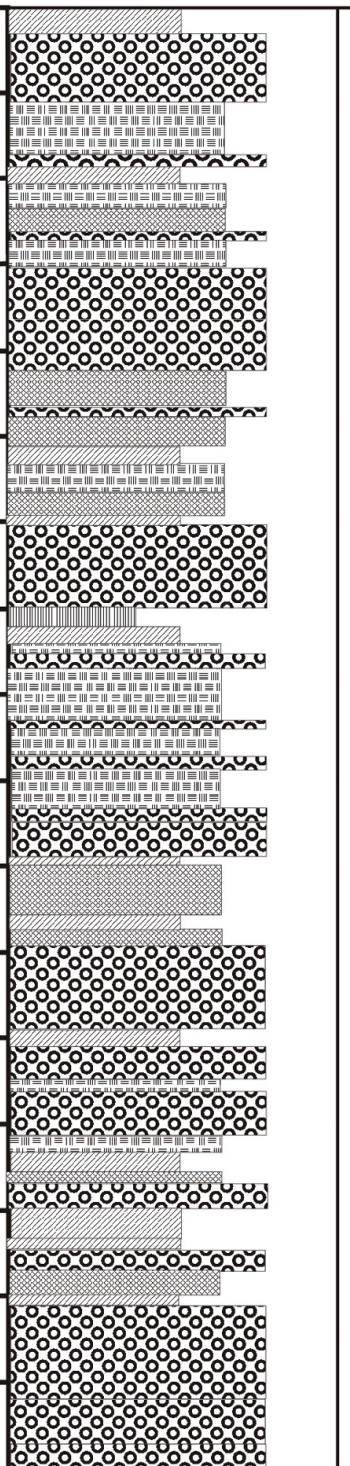 & 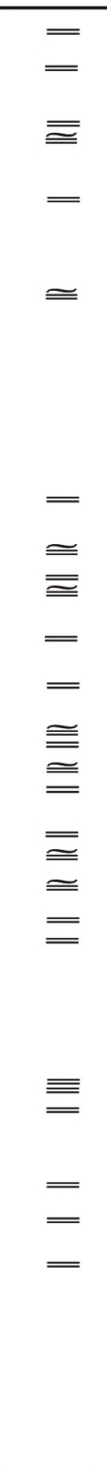 & $\begin{array}{l}2 \\
2 \\
2 \\
2 \\
2 \\
2 \\
2 \\
2 \\
2 \\
3 \\
2 \\
2 \\
2 \\
2 \\
2 \\
3 \\
2 \\
2 \\
2 \\
2 \\
2 \\
2 \\
2 \\
2 \\
2 \\
2 \\
2 \\
2 \\
2 \\
2 \\
2 \\
2\end{array}$ & $\begin{array}{c}\xi \\
\Psi \\
\xi \Psi \\
\xi \\
\xi \\
\xi \\
\xi \\
\xi \\
\xi \\
\xi \\
\xi \\
\xi\end{array}$ & 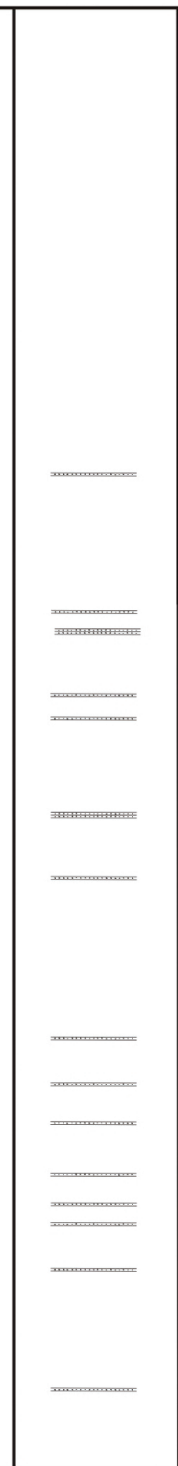 & - & 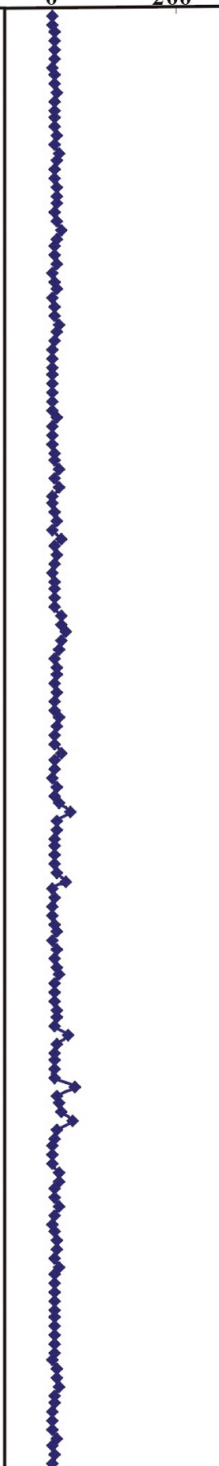 \\
\hline
\end{tabular}

Fig. 2. Columns showing the stratigraphy, lithology, sedimentary structures, faultrelated rock, vein distributions and fracture density. 


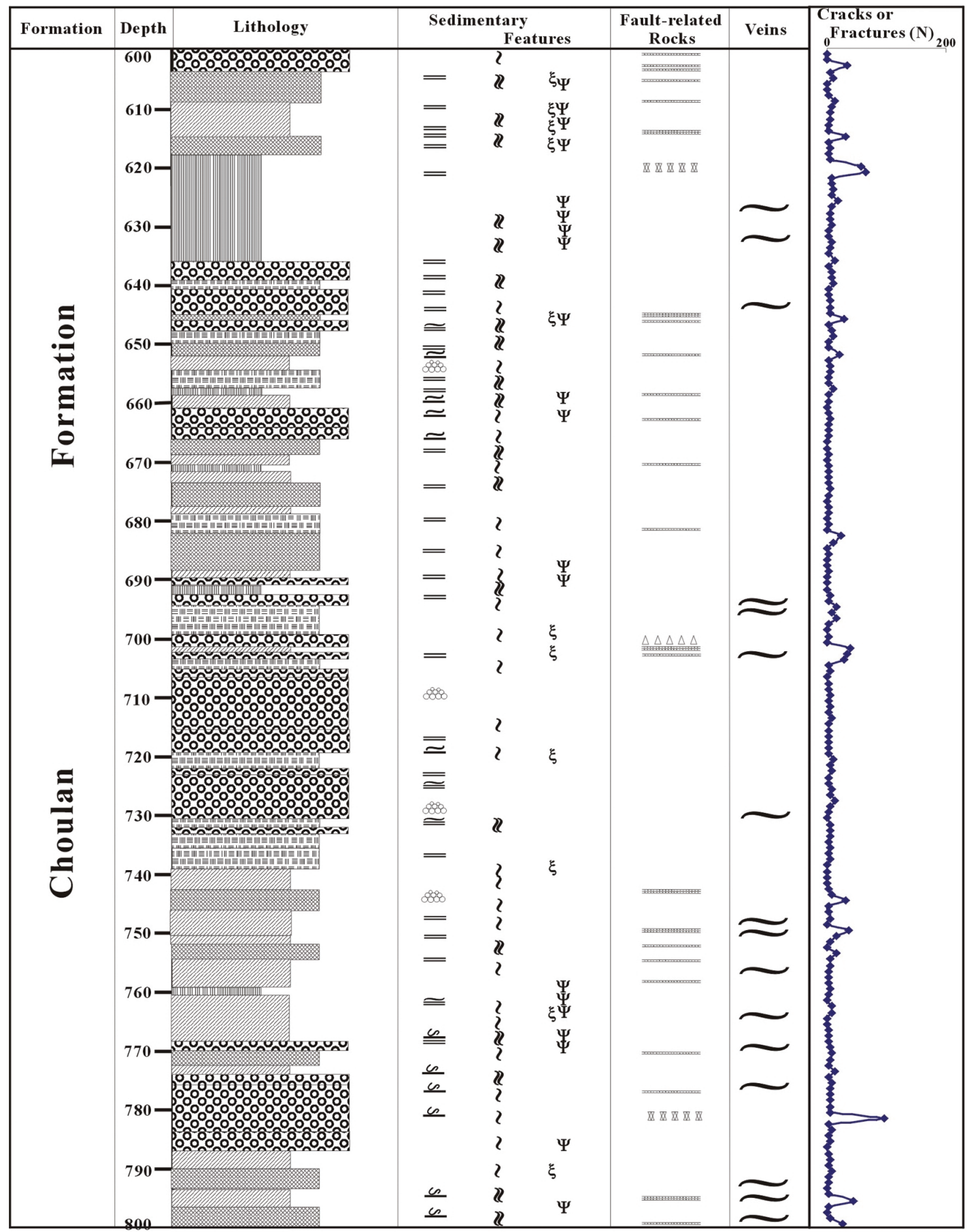

Fig. 2. (Continued) 


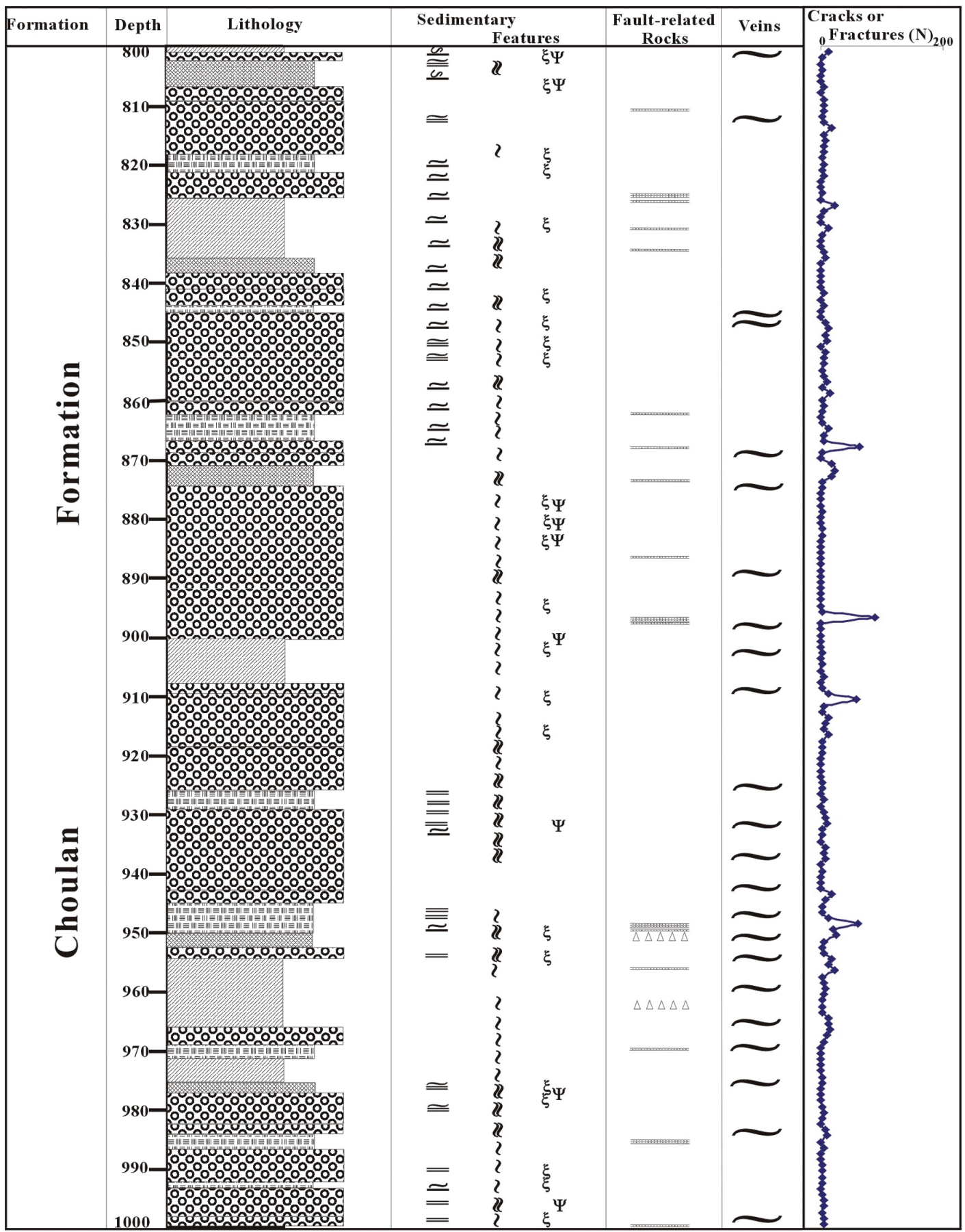

Fig. 2. (Continued) 


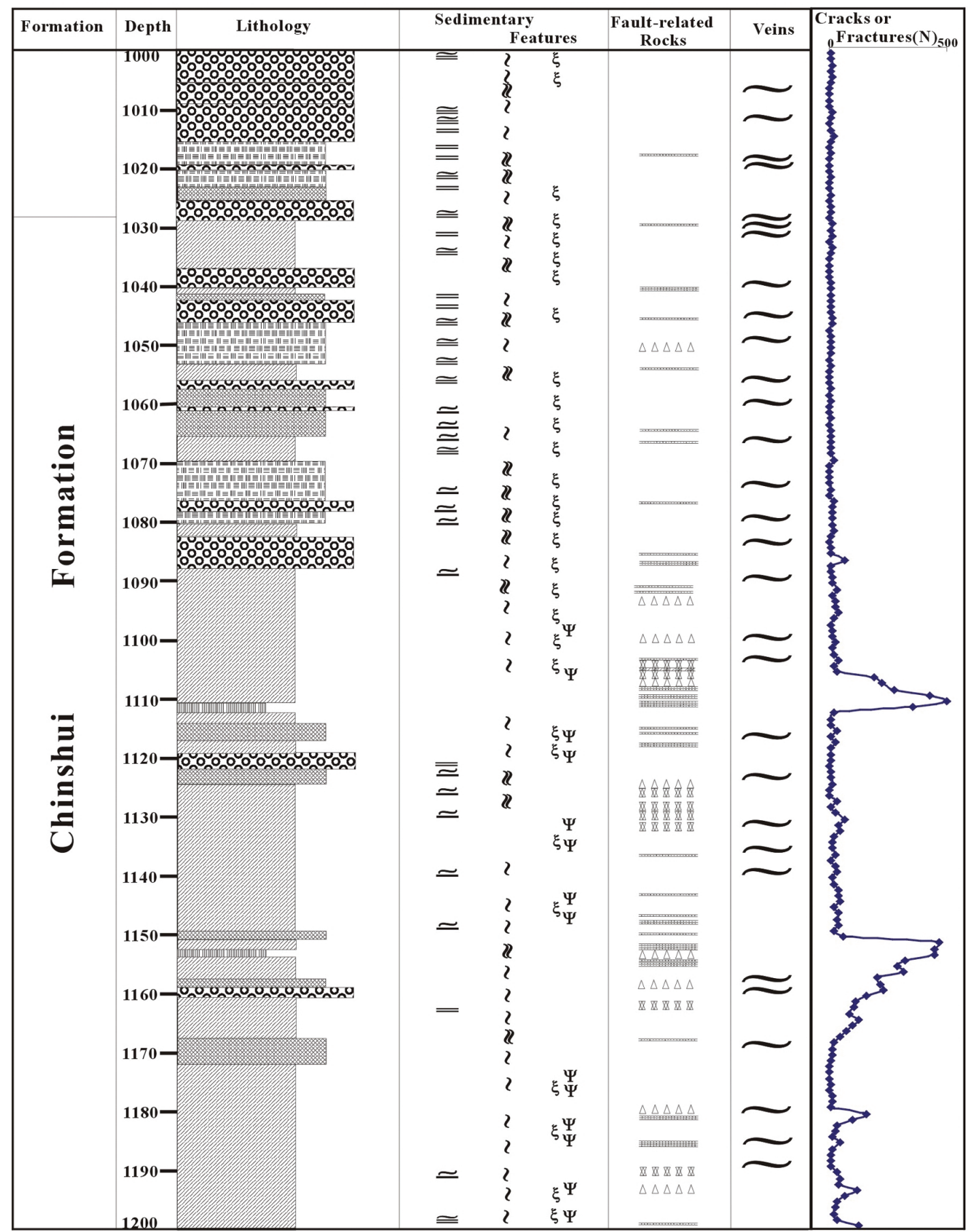

Fig. 2. (Continued) 


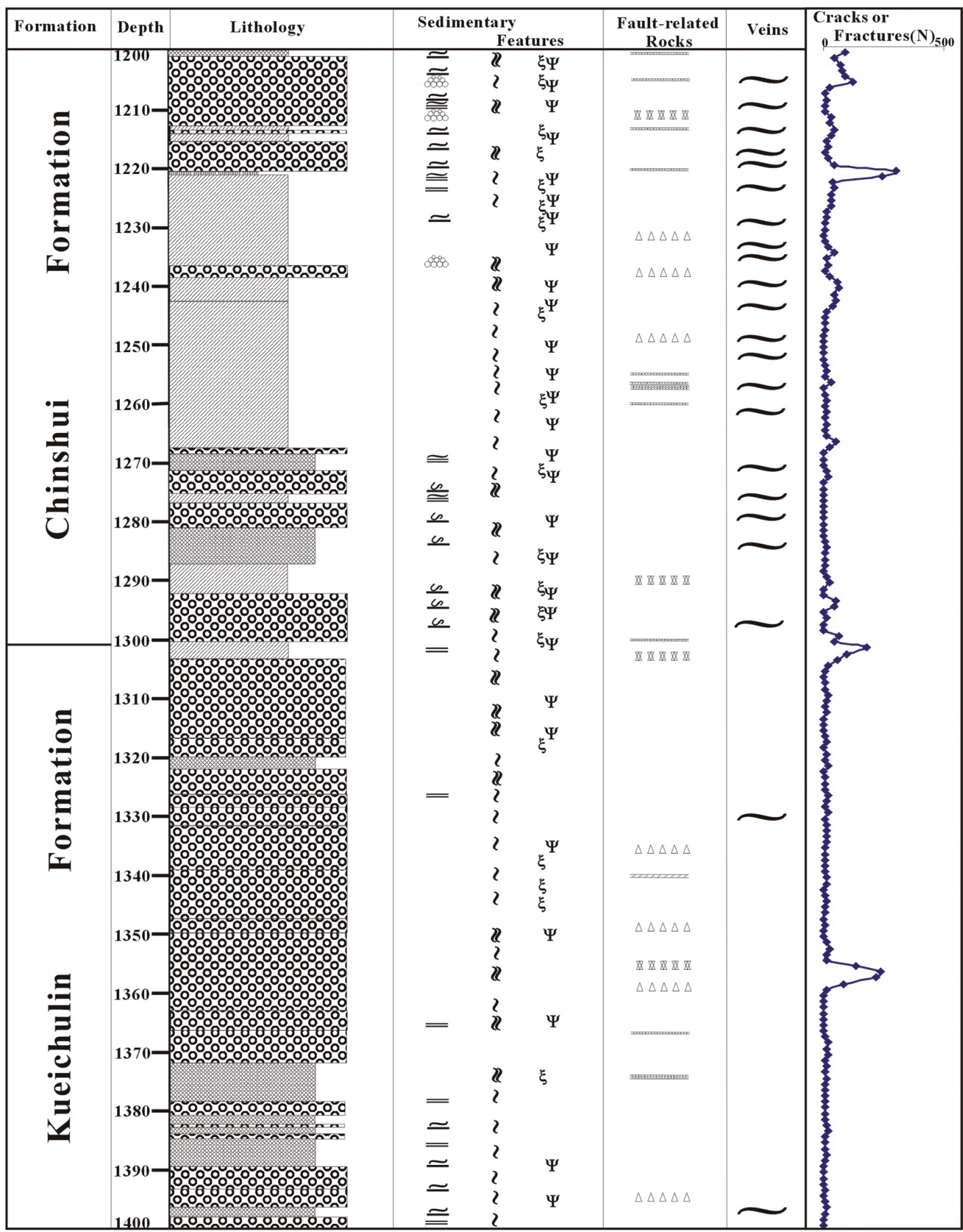

Fig. 2. (Continued) 


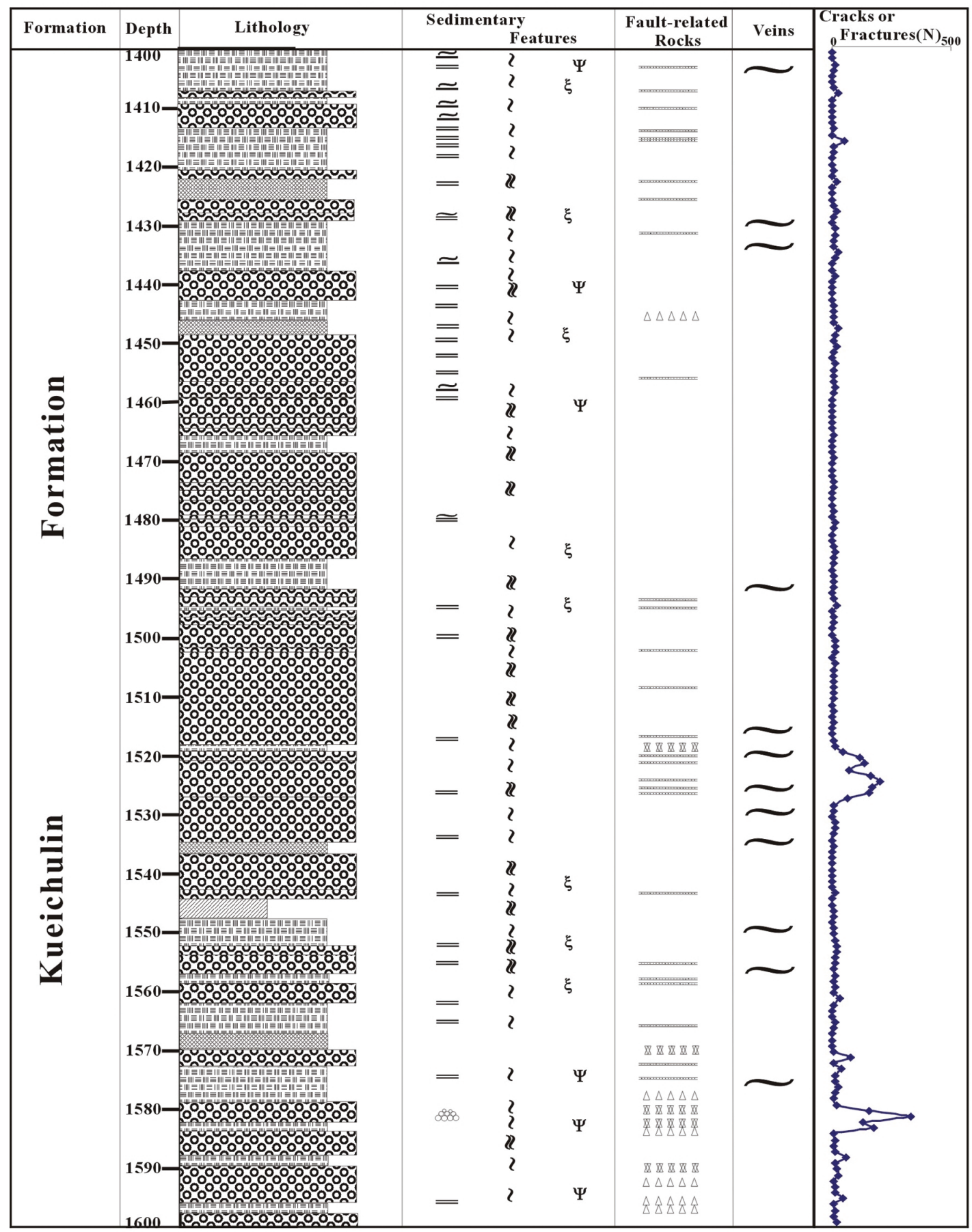

Fig. 2. (Continued) 


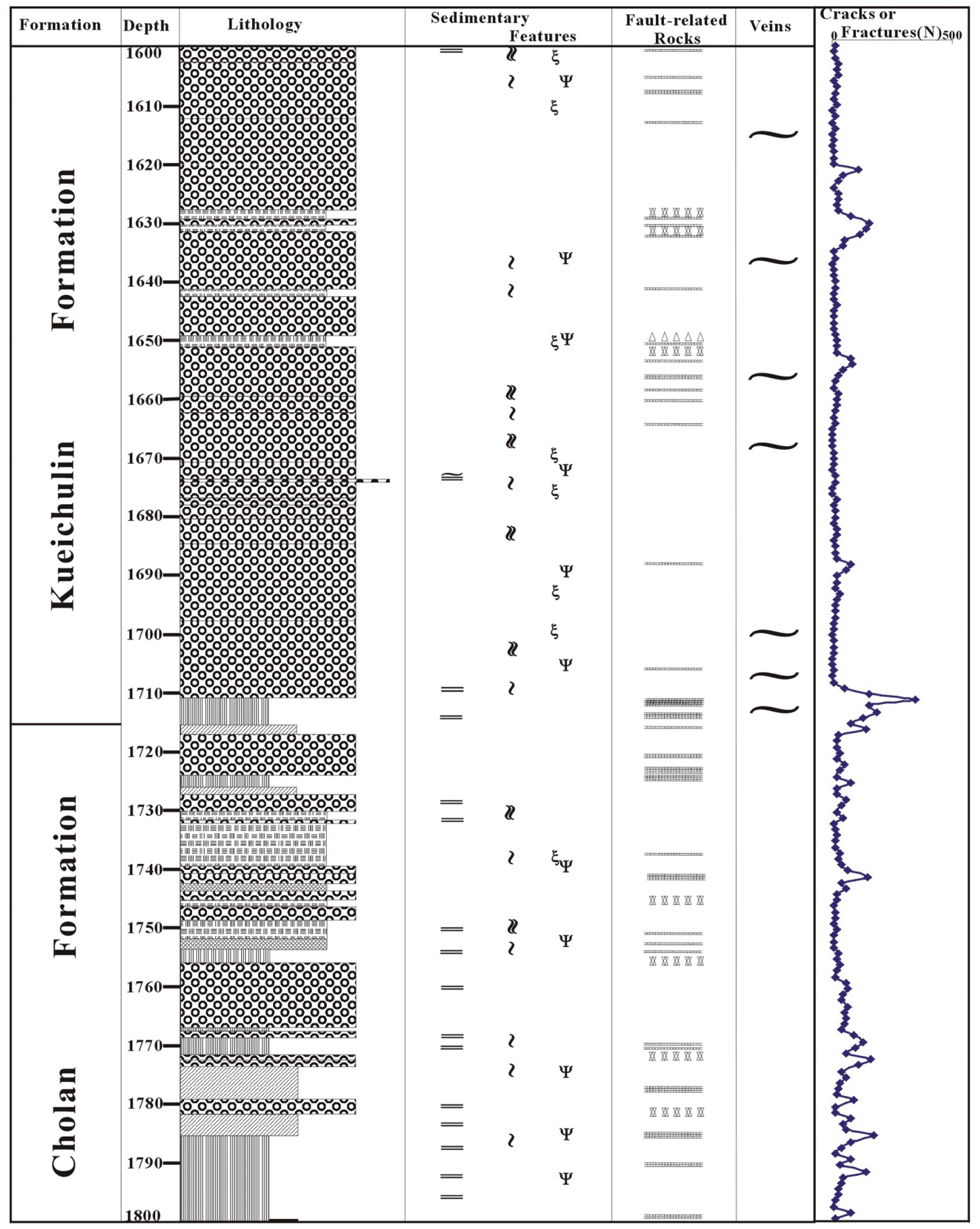

Fig. 2. (Continued) 


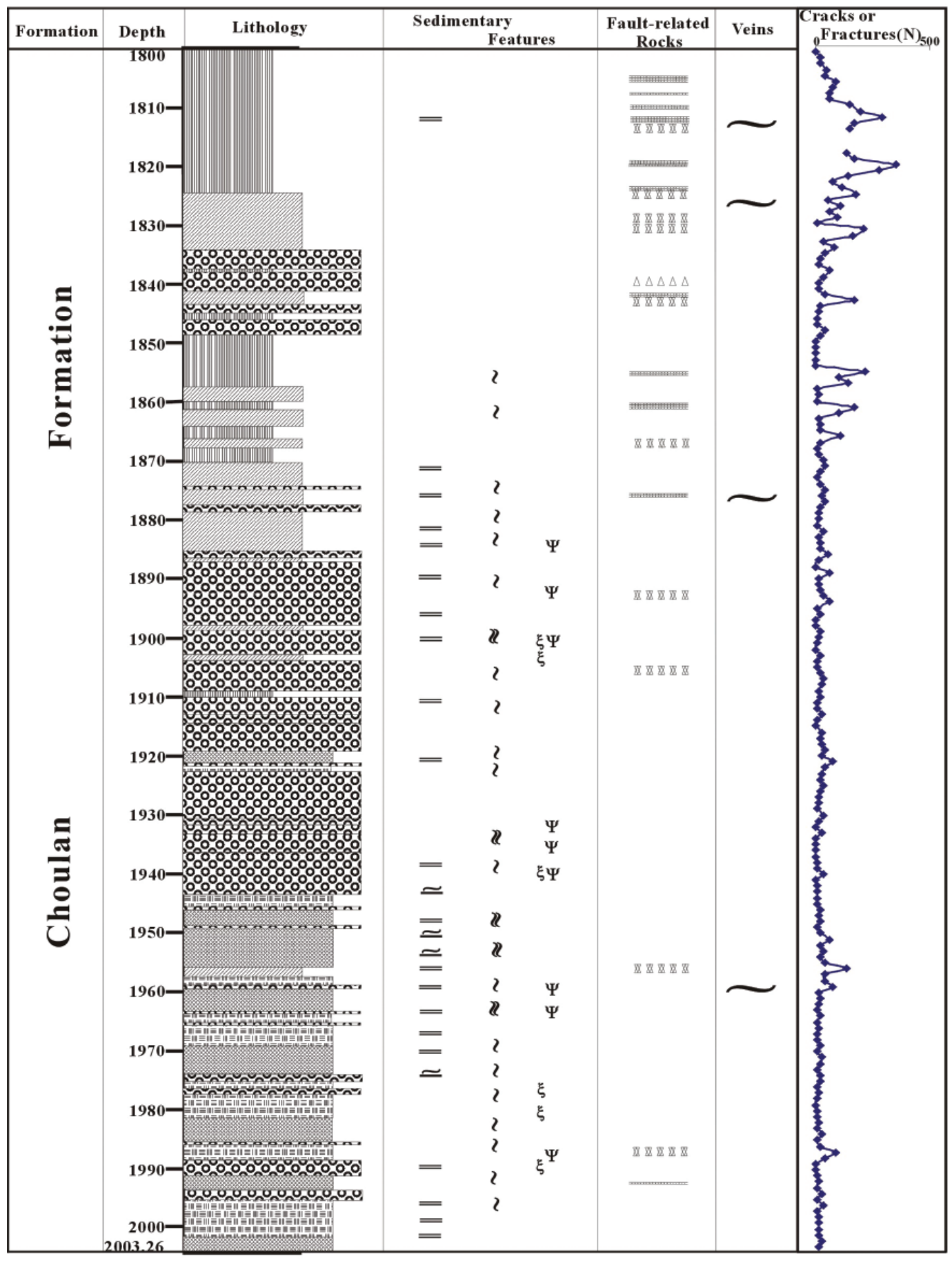

Fig. 2. (Continued) 
from rapid drilling mud loss, it has higher porosity. The principal sedimentary features of the sandstone are the wavy and lenticular beddings, the herringbone structure, the presence of transported shell fragments, mud draps, carbonaceous material, an upward coursing sequence assemblage and moderate bioturbations with the trace fossils, Zoophycus ichnofacies. These sedimentary structures and lithologic characteristics show that the Kueichulin Formation was deposited in a tidal-dominated delta system. This depth interval contains rare fossils which belong to the Pliocene fossil assemblage, no Miocene index fossils present, suggesting that the age of this part of the Kueichulin Formation is the early Pliocene (Wu et al. 2007).

\subsubsection{Cholan Formation (II)}

Below a depth of $1712 \mathrm{~m}$, the drill hit the younger Cholan Formation again, and this Formation continues until the end of the drilling at a depth of $2003.26 \mathrm{~m}$ (Fig. 2). Thick fractured rocks, gouges and fault breccias separate the overlying Kueichulin Formation and the underlying Cholan Formation. The lithology in this interval differs slightly from that above the Cholan Formation. Between the depths of 1767 and $1870 \mathrm{~m}$, the cores are characterized by thick, dark-gray mudstone with subsidiary sandstones and siltstones predominate. The mudstone is massive, highly fractured and rich with layers of large, pink mollusca fragments and foraminiferas with weak bioturbations (Fig. 3a). Measured from the core, the bedding dip angle above $1780 \mathrm{~m}$ is about $30^{\circ}$ (Figs. $3 \mathrm{~b}$, c), but it dramatically changes to $60^{\circ}-70^{\circ}$ right beneath $1785 \mathrm{~m}$ (Figs. 3d, e). This dramatic change in the bedding dip coupled with the richness in the fractured and sheared rocks leaves no doubt that the drilling had penetrated a major fault in this interval. Sandstone and alternating sandstone-siltstone with moderate to intense bioturbations characterize the composition of the 1870- to 2003.26-m deep interval. Rare fossils are found, but most are the secondary Miocene reworked fossils, Sphenolithus abies Deflandre. However, the fact that the Pleistocene to Holocene index nannofossils, Gephyrcapsa oceanica Kamptner (Wu et al. 2007) cannot be found in this interval is highly indicative that the age of the rocks belongs to the upper Pliocene.

\subsection{Types of Fault-Related Rocks}

Core inspection and analyses show that four types of fault rock, namely fault gouge (Figs. 4a, b), breccia (Fig. 4c), cataclasite (Fig. 4d) and pseudotachylyte, as well as two types of crackfilling are readily distinguished (Figs. 4e, f). The protoliths of the fault-related rocks are sedimentary rock which includes sandstone, siltstone and mudstone/shale with carbonate fossils and cement. These rocks are predominantly distributed in association with fault zones in the cores (Fig. 2).

Fault gouge is an incohesive, clay-rich, fine- to ultra-fine-grained rock with or without schistosity and has $30 \%$ visible fragments. It is generally a product of the comminution of faulting and is found in brittle faults on all scales (Sibson 1977; Wilson et al. 2005). In the cores, gouges, i.e., the random fabrics supported by pale gray or black matrix, are found from top to bottom (Fig. 2). The texture of the grain features in the host sedimentary rock is totally obliterated on the scale of a hand-specimen. However, some gouges have developed foliated fab- 
rics which are characterized by compositional banding with a preferred alignment of fragments. Gouges of various thicknesses, ranging from just a few millimeters to over a meter, are widely distributed throughout all of the cores (Fig. 2). What this demonstrates is that minor faults with different orientations had commonly developed, indicating that superimposed shear deformations also occurred. Several thick gouge layers (over $20 \mathrm{~cm}$ ) are found around the depths of $1111,1153,1222,1580,1712$, and $1812 \mathrm{~m}$, and it is precisely these that are generally identified as the cores of the major fault zones. Among them, at a depth of around $1111 \mathrm{~m}$ is the fault core of fault zone FZ1111, which consists of more than 1-meter long pale-gray gouges (Fig. 5a) with black material about $12 \mathrm{~cm}$ in thickness. It is important to note that this black material with slickenline and foliated fabric may very well, in fact, be the slip zone of the 1999 Chi-Chi earthquake.

Fault breccia is a medium- to coarse-grained rock containing $>30 \%$ visible fragments. In the TCDP Hole-A cores, fault breccias are readily distinguished by the fragment-supported random fabrics (Fig. 4c), and they are commonly associated with fault gouges in the major fault zones (Fig. 2). Their thickness ranges from several centimeters to meters. Fragments from them are between several millimeters and centimeters in diameter and are commonly angular or lenticular in shape. The filling matrix is pale gray in color and is identical to the clay gouges. Fault breccias are usually made of the damage zone of the major faults.

Cataclasites are usually cohesive and have a poorly developed or even absent schistosity, or if they are incohesive, they are generally characterized by angular porphyroclasts and lithic fragments in a fine-grained matrix of similar composition. A cataclasite is a random fabric rock product of friction-dominated faulting within a seismogenic regime which typically occurs in the top $10-15 \mathrm{~km}$ of actively deforming continental crust (Sibson 1977). Cataclasites are observed in the cores as indurated rock composed of a dark gray matrix and light-colored, sub-angular to sub-rounded fragments of sedimentary lithics or quartz grains. They are commonly associated with the gouges of major fault zones.

Pseudotachylyte is a dark, extremely fine-grained, often glassy rock forming veins or dikes, typically associated with shear zones or faults. It is interpreted as large fossil remnants from paleoseismic events, usually with a magnitude larger than 6.0 (Sibson 1975; Magloughlin and Spray 1992; Toyoshima et al. 1994; Lin et al. 2001; Theunissen et al. 2002). In TCDP Hole-A, pseudotachylyte can only be observed under a transmitted electron microscope (TEM) at a depth of $1111.29 \mathrm{~m}$ (Kuo and Song 2005). From this, it is inferred that the activity of the Chelungpu fault had previously experienced a large quick displacement from a seismic event.

Mineral fillings are very common and are highly associated with fractures in the 880- to 1280-m depth interval of the core (Fig. 2). Most are composed of carbonate which may have been precipitated from over-saturated bicarbonate fluids in the pore space or which may have come as inflow from the surface. Two types of filling are distinct. The first are thick crackfilling veins, while the second are very thin step-fillings on the sinitral fault plane. The former are distributed throughout the core, whereas the latter are just above the 1300-m depth. They range from sub-millimeters to centimeters in thickness. Based on the cross-cutting relationship between the open-crack veins and the step-fillings, the sinistral fault could have possibly been an older deformation. 


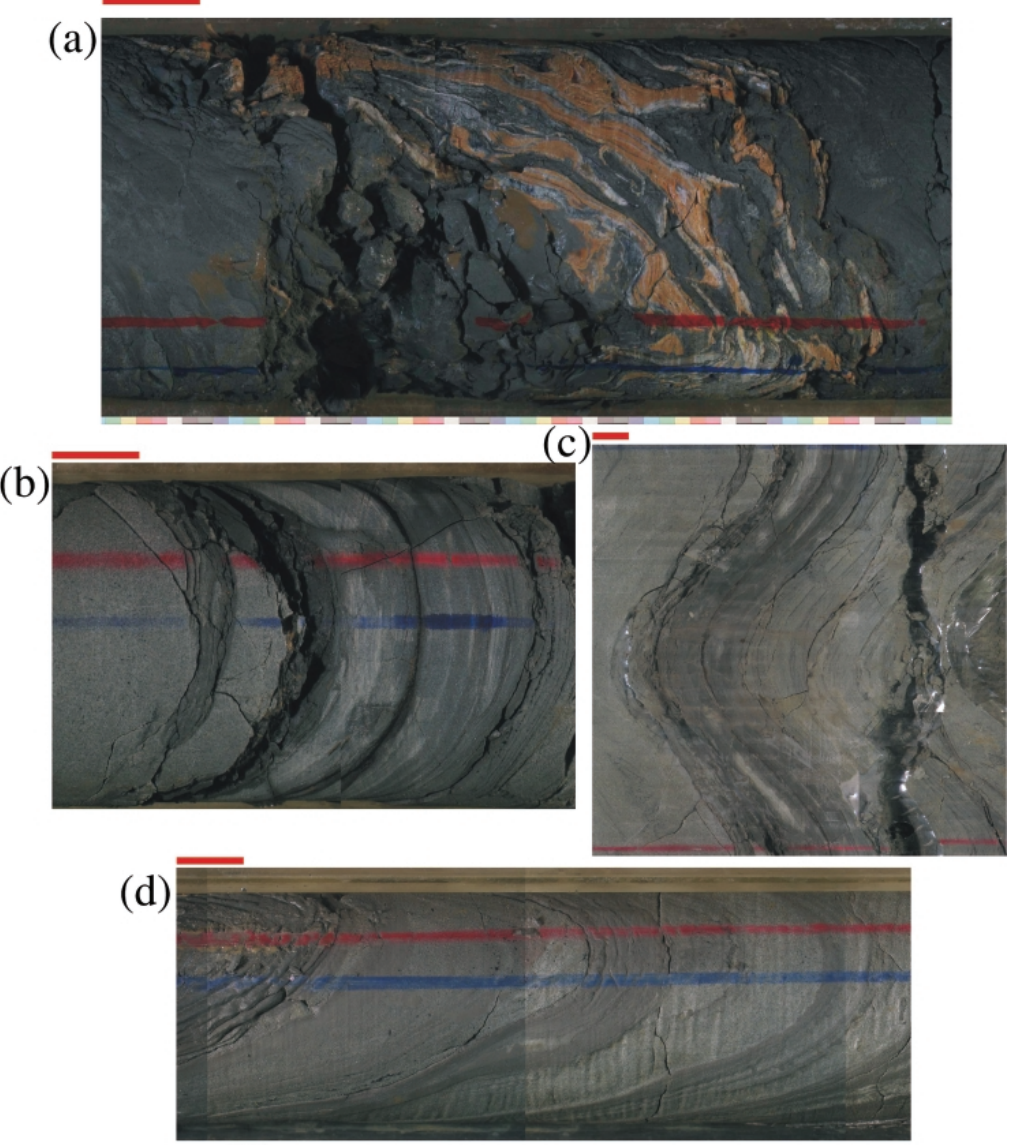

(e)

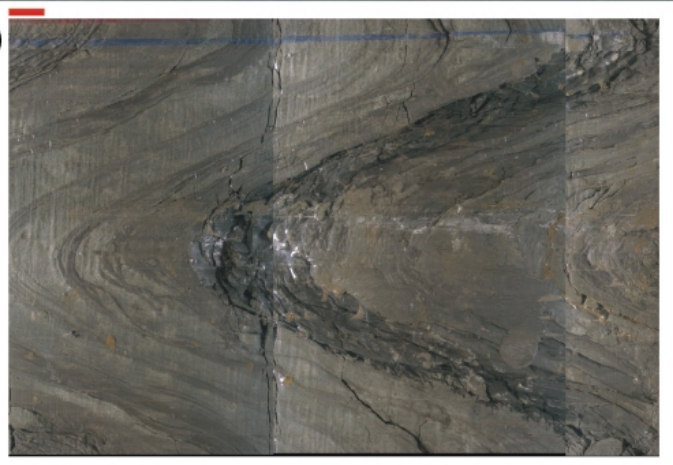

Fig. 3. Photographs showing the characteristics of cores: a) Thin mollusca layer at a depth of $1755 \mathrm{~m}$ which is a typical characteristic of the upper Cholan Formation; b) Small bedding dip (about $30^{\circ}$ ) of a slab scanning image; c) Small bedding dip (about $30^{\circ}$ ) of an unrolled scanning image; d) Large bedding dip $\left(60^{\circ}-70^{\circ}\right)$ of a slab scanning image; and e) Large bedding $\operatorname{dip}\left(60^{\circ}-70^{\circ}\right)$ of an unrolled scanning image. Red bar is $2 \mathrm{~cm}$. 
(a)

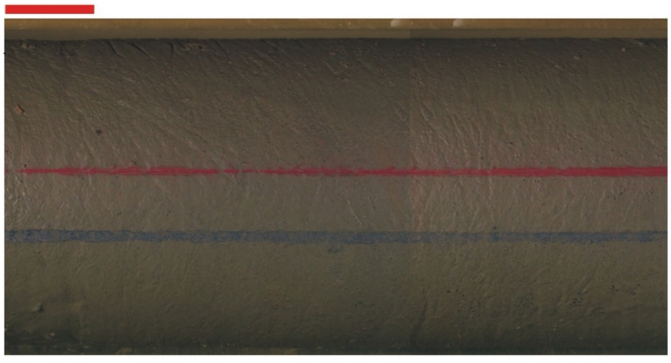

(b)

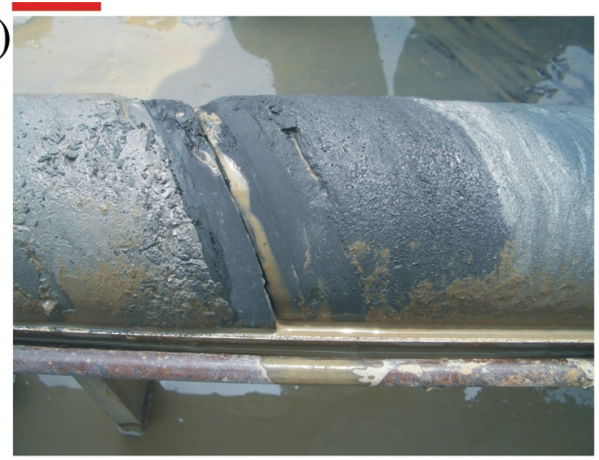

(c)

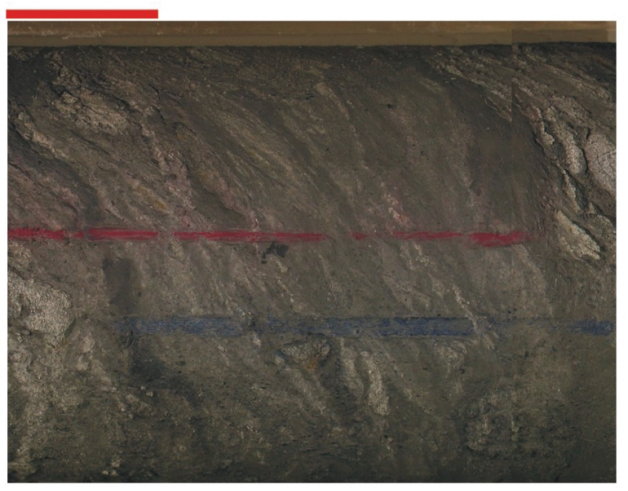

(d)

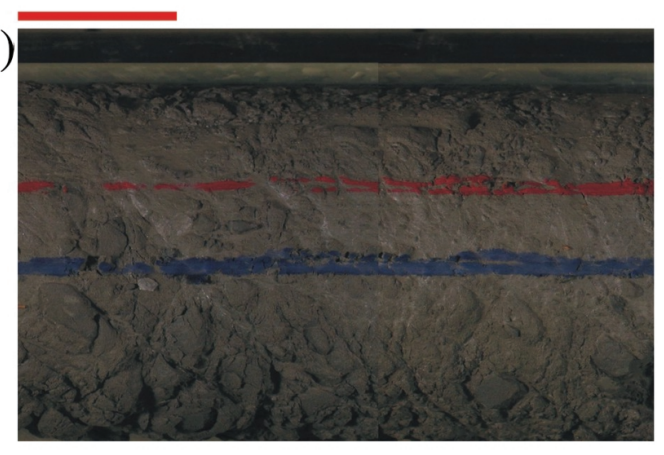

(e)
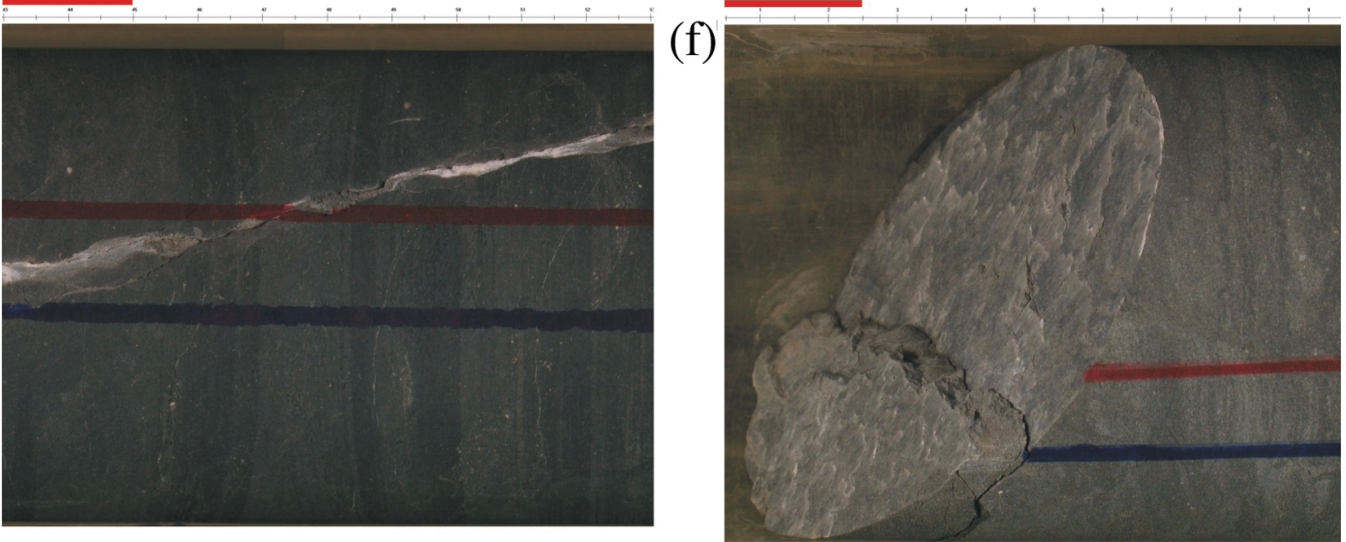

Fig. 4. Photographs showing fault-related rocks and veins: a) Occurrence of light gray fault gouges at a depth of $1110.5 \mathrm{~m}$; b) Occurrence of black fault gouges at a depth of $1111.26 \mathrm{~m}$; c) Occurrence of fault breccias at a depth of $1110 \mathrm{~m}$; d) Occurrence of foliated cataclasite at a depth of 1111. $10 \mathrm{~m}$; e) Occurrence of very thin calcite veins filling up on the surface of slicken-side; and f) Occurrence of thicker calcite veins filling up the cracks. Red bar is $2 \mathrm{~cm}$. 
(a)

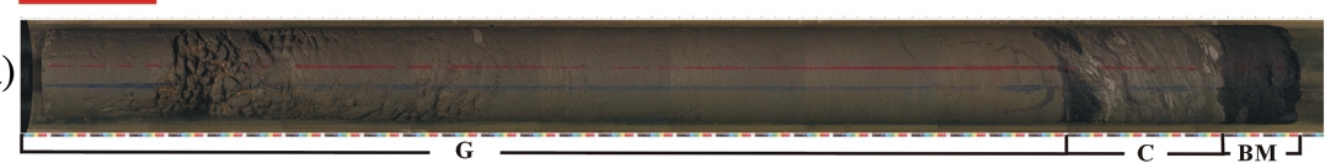

(b)

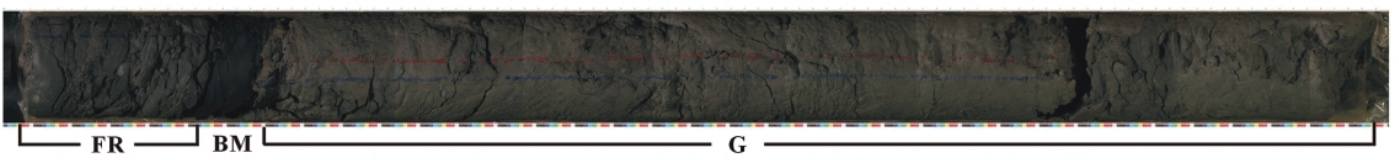

(c)

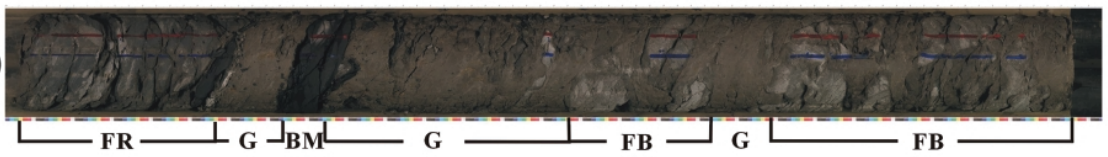

(d)

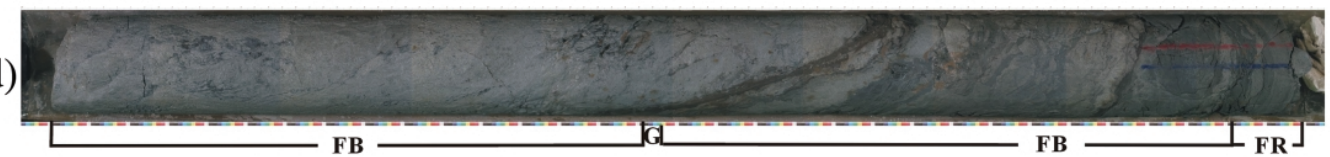

(e)

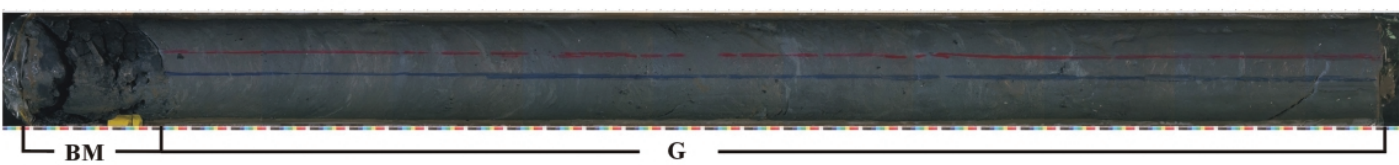

(f)

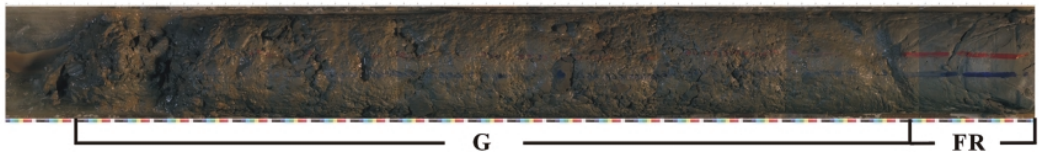

Fig. 5. Photographs of the fault cores in the six fault zones: a) FZ1111, the depth from 1110.37 to $1111.29 \mathrm{~m}$; b) FZ1153, the depth from 1151.3 to $1152.26 \mathrm{~m}$; c) FZ1220, the depth from 1220.5 to $1221.28 \mathrm{~m}$; d) FZ1580, the depth from 1581.2 to $1582.1 \mathrm{~m}$; e) FZ1712, the depth from 1711.7 to $1712.7 \mathrm{~m}$; and f) FZ1812, the depth from 1811.5 to $1812.19 \mathrm{~m}$. Red bar is $10 \mathrm{~cm}$. G: gouge; C: cataclasite; BM: black materials; FR: fracture rock; FB: fault breccia.

\subsection{Fault Zone Structures}

A fault zone is defined as a zone of sheared, crushed or foliated rock in which numerous small dislocations occur, making for an appreciable total offset on the undeformed walls. It can be divided into three distinct components: a fault core, where most of the displacement is accommodated, an associated damage zone that is mechanically related to the growth of the fault zone and protolith, which is original rock that is basically left undamaged by faulting (Chester and Logan 1986; Foster and Evans 1991; Scholz and Anders 1994; Caine et al. 1996). 
As a rule, a fault core is predominantly composed of clay gouges produced by comminution from faulting and/or chemical alterations, while the damage zone is characterized by subsidiary faults, fractures, veins, foliation and folding (Chester and Logan 1986; Caine et al. 1996). Based on our examination of the cores and the distribution of the fault rocks in the TCDP Hole-A cores, there are at least six distinct major fault zones: FZ1111, FZ1153, FZ1220, FZ1580, FZ1712, and FZ1812 down-hole. The numbers after FZ stand for the depth of the core. The characteristics of each fault zone are described in detail below.

Depths from 1106.29 to 1111.79 m make up fault zone FZ1111, and it is characterized by a sharp increase in fracture density (Fig. 2). Consisting of clay gouges of the fault core between 1110.37 to $1111.34 \mathrm{~m}$, it is surrounded by the damage zone (Fig. 5a), which is highly asymmetric, with the hanging wall being thicker than the footwall. The clay gouges are composed of thick, massive, pale-gray clay with numerous small fragments and thin layers of foliated cataclasite and black material. The foliated cataclasite has a mixed, wavy texture about $13 \mathrm{~cm}$ in thickness, and it consists of laminations of white intercalated with dark gray, finegrained rock (Fig. 5a). Just beneath the cataclasite down hole, a black gouge about $12 \mathrm{~cm}$ thick with sharp contact to the cataclasite is observed at $1111.37 \mathrm{~m}$ down. It is composed of very fine-, nannosize-grained (10 - $300 \mathrm{~nm}$ ) clay with poorly foliated and slickenline structures. Pseudotachylyte has only ever been found in the black material of the cores (Kuo and Song 2005). The damage zone is composed of fault breccias and fractures which increase toward the fault cores with two thin layers of gouge.

Fault zone FZ1153 is identified in the 1142.30- to $1167.85-\mathrm{m}$ depth interval of the cores and is about $25.5 \mathrm{~m}$ thick, making it thicker than FZ1111 (Fig. 5b). Between 1152.96 and $1153.75 \mathrm{~m}$, it consists of clay gouges of the fault core, and it is surrounded by the damage zone which is highly asymmetric, with the footwall being thicker than the hanging wall. The clay gouges are composed of thick, massive, brownish-gray, sandy clay with small fragments and two thin layers of black material. Compared with those in FZ1111, the gouges are coarser in terms of particle size, and they contain more pore water. The two layers of black material are composed of very fine-grained clay, and they have a poorly foliated structure. The damage zone consists of 1.2-m thick foliated breccias, thin black material $(3 \mathrm{~cm})$ and a very thick fracture zone with fracture density increasing toward the fault core.

FZ1220 occurs in the 1118.15- to 1221.93-m depth interval. With a thickness of about $3.78 \mathrm{~m}$, it is the thinnest fault zone among all of the cores. It is composed of $20-\mathrm{cm}$ long, brownish-gray and black gouges in the fault core surrounded by asymmetric fault-related rock in the damage zone (Fig. 5c). Two black fault gouges in the fault cores, with the respective thickness of 1 and $3.5 \mathrm{~cm}$, are hard, dry rock, while the brownish-gray gouges are soft and wet. The damage zone is characterized by highly dense fractures with the fracture density increasing toward the fault core. There are also thin layers of gouge on the hanging wall. Apart from this, about $65-\mathrm{cm}$ thick breccias are found with two thin layers of black material and high fracture distributions immediately following the breccias on the footwall.

When drilling through the Chinshui Shale into the sandstone-dominated Kueichulin Formation, fault zone FZ1580 was found in the 1580.05 - to $1583.85-\mathrm{m}$ depth interval where the boundary is a high angle shearing plane cutting through the bedding. It is composed of very thin fault gouges, and it has an asymmetric damage zone (Fig. 5d). Dark brown in color, 
the fault gouges are about $5 \mathrm{~mm}$ thick, and they have a high angle dip cutting through the sedimentary bedding. The damage zone in the hanging wall is predominantly composed of high-shearing, sandy fault breccias with thin gouge veins and fractured sandstone with microfaults. Contrast this with the footwall which is predominated by sheared and fractured alternating sandstone and siltstone with many micro-faults, breccias and veined gouges with blocks of black material.

Further down at $1710 \mathrm{~m}$, fault zone FZ1712 is identified at depths between 1709.95 and $1716.70 \mathrm{~m}$ (Fig. 5e). It is composed of thick gouges of fault core and asymmetric damage zone. The fault core is about $1.07 \mathrm{~m}$ long and is characterized by massive, poorly-foliated, brownish-gray gouges with numerous black fragments and about $10-\mathrm{cm}$ thick black material. The thin, fractured rocks about $60 \mathrm{~cm}$ in thickness in the hanging wall make for a striking contrast to the footwall which contains thick fault breccias about $370 \mathrm{~cm}$ long with thin layers of gouge. The dip of the fault plane is also very steep, about 60 - 70 degrees.

The last fault zone is found between the depths of 1811 and $1821.71 \mathrm{~m}$, and it has a total thickness of about $10.71 \mathrm{~m}$. It is hard to define the exact fault architecture on account of the poor coring quality at these depths. Approximately $10-\mathrm{cm}$ thick and gray with thin black gouges (Fig. 5f), it is a fault core surrounded by the thick damage zone. The damage zone is asymmetric, and the hanging wall which contains fault breccias is about $60 \mathrm{~cm}$ thinner than the footwall which is composed of breccias, gouges and fractured rocks.

\section{DISCUSSION AND CONCLUSIONS}

Taiwan is located within the complexity of the oblique collision zone of the Eurasian continental plate and the Philippine Sea plate since $10 \mathrm{Ma}$ (Teng 1987, 1990). Currently, it is believed that the mountain-building process is still in progress (Tsai et al. 1981; Yu and Chen 1994; Yu et al. 1999). Rapid uplifting and the erosion of orogenic mountain ranges have resulted in the dumping of large amounts of sediment into the foreland basins of western Taiwan. Although the source of the sediment was originally in the west, it evidently changed to the east during the collision. This process has accumulated huge sedimentary piles of Plio-Pleistocene sequences, the thickness of which is over 4000 - $5000 \mathrm{~m}$ in the Western Foothills of Taiwan. Though the sediments were originally deposited in shallow marine environments, they gradually changed with them later being dumped in delta or fluvial environment (Chou 1977; Covey 1984). Based on the limited and discontinuous surface outcropping, three distinct formations are recognized. From oldest to youngest, they are the Chinshui Shale, the Cholan Formation and the Tokoushan Formation (Chou 1977; Chi and Huang 1981). The formation boundaries of these are, nevertheless, somewhat ambiguous largely in part because of poorly exposed outcrops and changes in the lithofacies or perhaps even the mishandling of samples on the part of the field geologists.

The drilling of the TCDP Hole-A yielded one of the longest and most continuous cores ever welled at a depth of $2003 \mathrm{~m}$. It covers stratigraphy dating from the late Miocene to the late Pliocene and even into the early Pleistocene Formations in Taiwan. Total recovery of the core in TCDP Hole-A was almost 97\%, and most of the core is continuous. In addition to this, there 
was no distinct disturbance on the cores of either the protolith or the fault zones. Further, the sedimentary and bioturbated structures, such as many kinds of bedding and trace fossils as well as lithology were also very well preserved. This core, therefore, provides the best opportunity for sedimentologists as well as field and tectonic structural geologists alike to study the stratigraphy, sedimentation and environmental changes, not to mention the tectonics of western Taiwan during orogenic processes in the Plio-Pleistocene.

Based on the lithology and the findings from field work, the assemblages of the finergrained sedimentary rocks which were deposited in a shallow marine environment and which are predominant in the shale have been named the Chinshui Shale (Ando 1930). It is characterized by dark, massive, fine-grained sedimentary rock, shale with thin layers of sandstone and/or alternating sandstone and shale. The Chinshui Shale is found in the 1027- to $1303-\mathrm{m}$ depth interval in TCDP Hole-A. The total thickness of the core is about $240 \mathrm{~m}$ which is a little thinner than the surface outcrop of type locality. The boundary between the Chinshui Shale and the Cholan Formation is the first appearance of thick, black siltstone right beneath the thick sandstone with intensive bioturbation, while the boundary with the Kueichulin Formation is the thick sandstone below the thick siltstone. The Chinshui Shale is predominantly composed of siltstone and minor alternates of sandstone-siltstone with very little shale, which makes it quite different from the original definition of Chinshui Shale. However, it must be pointed out that field geologists and sedimentologists in Taiwan have customarily considered fine-grained sedimentary rock, siltstone and shale the same in the field (personal communication with Dr. W. S. Chen among others). Thus, on the basis of the valuable lithological data from TCDP Hole-A, we are strongly of the view that hereafter the Chinshui Shale should be renamed the Chinshui Formation.

One of the main targets of the TCDP was to drill through an active fault zone at deep after the recent major earthquake, the 1999 Chi-Chi earthquake. The purpose has been to investigate the physical and chemical properties of the material in the seismic fault zones as well as the mechanisms of faulting. Deeming this project a success is dependant on whether the drilling hit the slip zone of the Chi-Chi earthquake or not. The drilling site is located in the Takung area, Taichung city, which is about $2 \mathrm{~km}$ to the east of the surface rupture of the Chelungpu fault. The fault plane dip was about $30^{\circ}$ to the east (Yeh et al. 2007). The shallow seismic reflective results obtained here also indicate that the fault plane dip is about $30^{\circ}$ to the east at depth (Wang et al. 2007). Thus, based on surface rupture, the regional geology and the seismic reflection data, the Chelungpu fault slipping plane is probably located at depths between 900 and $1200 \mathrm{~m}$. Having designed a drill hole about $2000 \mathrm{~m}$ deep, we had no problem whatsoever hitting the slip zone, and besides this, there was also a great possibility that we found the Sanyi fault within the same $2000 \mathrm{~m}$ (Wang et al. 2007).

At least six fault zones are identified in the core: three at depths from 1100 to $1220 \mathrm{~m}$ and the others at depths greater than $1580 \mathrm{~m}$. The shallower three are located in fine-grained dominated rock of the Chinshui Formation, where most of the slip and fault planes are parallel to the beddings. The composition of the fault core gouges in these three fault zones is quartz and clay minerals, which are dominated by the illite, chlorite and kaolinite. However, pseudotachylyteand smectite-rich material reaching about $85 \%$ of the clay minerals occurs in a very narrow 
zone in the black material of fault zone FZ1111 (Kuo and Song 2005). The well logging data show that the depth range from 1108.75 to $1113.25 \mathrm{~m}$, which accommodates fault zone FZ1111, has sharply decreased resistivity and permeability, the lowest density, Vp and Vs, as well as high Vp/Vs, Poisson's ratio and fluid contents (Hung et al. 2005). More than that, on-line gas monitoring shows anomalously high $\mathrm{CO}_{2}$ and $\mathrm{CH}_{4}$ gas contents in this depth range (Yang et al. 2005). On the weight of all this evidence, it is strongly believed that the Chelungpu-fault slip zone of the 1999 Chi-Chi earthquake was located in fault zone FZ1111 (Fig. 6).

The Sanyi fault is a thrust fault located in the frontal zone of a fold and thrust belt in the Western Foothills of central Taiwan. As a major boundary fault dividing the Western Foothills and the Taichung piggyback basin, it had a dip of about $40^{\circ} \sim 70^{\circ}$ to the east and its strike was northeast (Lee 2000). To the north of the Tachia River, the Miocene Nanchung Formation thrusts up to the late Pleistocene Toukoshan Formation, while in the southern part, the late Miocene Kueichulin Formation thrusts up to the Toukoshan Formation (Lee 1994). It has been suggested that it merges with the Chelungpu fault south of Taichung (Lee 2000). Evidently, however, there was no active co-movement during the 1999 seismic event.

In the core, the original bedding dip dramatically changes from $30^{\circ}$ to $60^{\circ}-70^{\circ}$ directly beneath $1780 \mathrm{~m}$ (Fig. 3b). The bedding between the depths of 1712 and $1780 \mathrm{~m}$ is unclear due

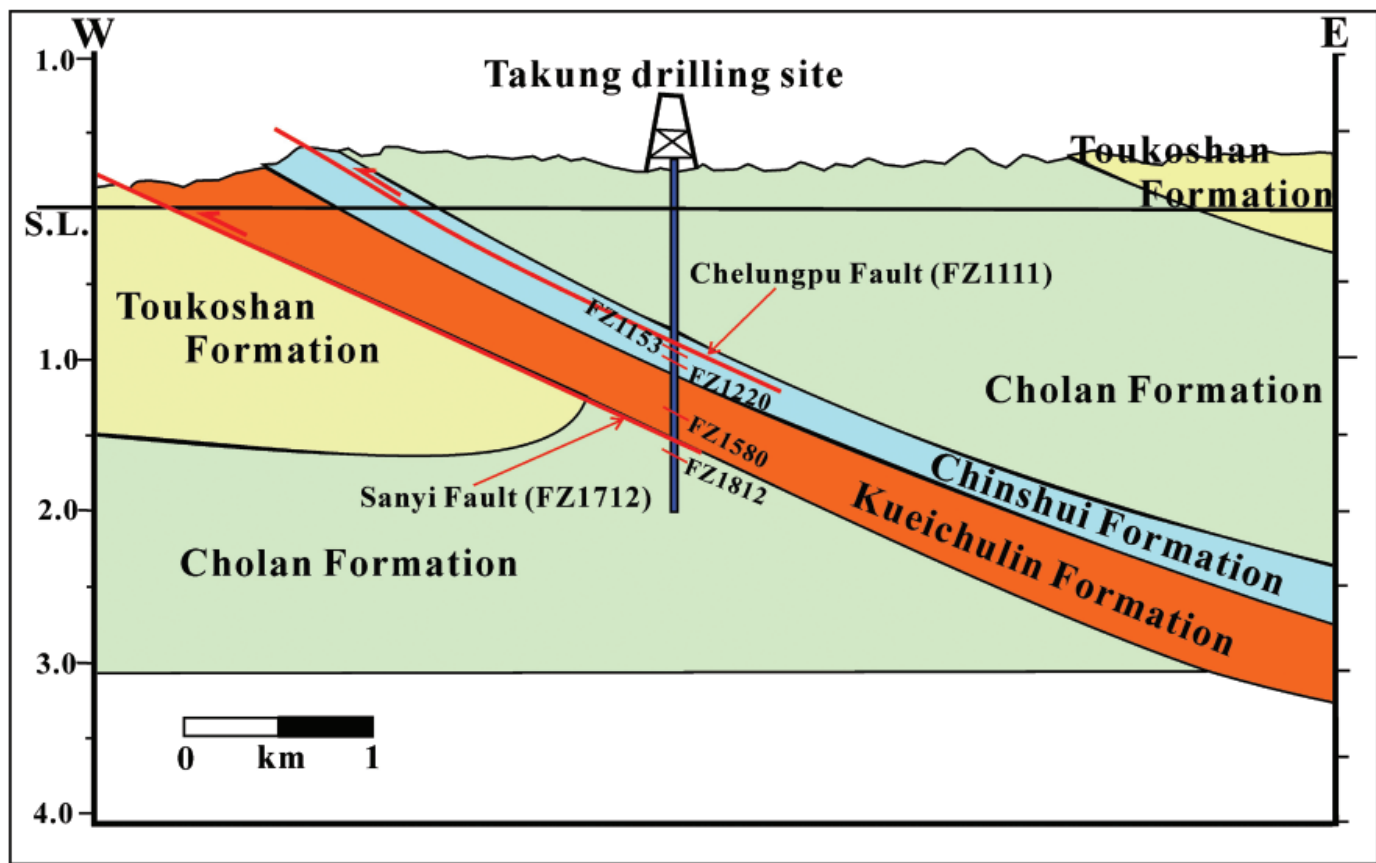

Fig. 6. Schematic geological cross-section showing the relationships among the fault zones, the stratigraphy and the major faults in the TCDP Hole. 
to faulting or disturbance from the coring. Stratigraphically, the down-hole formation drastically changes from the Miocene Kueichulin Formation to the late Pliocene Cholan Formation at a depth of $1716.7 \mathrm{~m}$, where fault zone FZ1712 is accommodated. Obviously, it can be inferred that fault zone FZ1712 is a major thrust fault. Interestingly indeed, when the surface trace of the Sanyi fault, the regional geology and the seismic reflection profile are correlated (Wang et al. 2007), it becomes quite clear cut that the fault located at the 1712-m depth may very well be the Sanyi fault. Although the surface footwall outcrop of the Sanyi fault to the south of the Tachia River is the Toukoshan Formation, it is also reasonable to conclude that on account of the out-of-sequence thrust, the Cholan Formation is in the deeper footwall (Fig. 6).

Based on the core descriptions and the scanning core images, the architecture of the fault zones is highly asymmetric. For example, with respect to the thrusting fault zone from top to bottom, the architectural pattern of FZ1111 changes from fractured to intensely fractured, breccia, gouge, black material and finally to a thin-layered breccia zone or fracture zone. Thus, the damage zone is thicker above the fault core than below it, while the lower boundary appears sharper when compared to the broad upper transient boundary. Against this, FZ1153 has a reversed structural pattern, with the damage zone being thinner above the fault core than below it. In some fault zones, nevertheless, the gouges and coal-like material are at the top, while the breccia zones and fractured zones are at the bottom. A fault zone with asymmetric architecture has also been reported in the drilling of the Nankai trough. Using numerical simulations, some researchers have recently advanced the view that a wrinkling-like pulse is the driving force that results in the development of an asymmetric fault zone.

Acknowledgements The authors would like to thank many research assistants, drilling technicians, students and volunteers for their assistance with the on-site work of the TCDP. This research was supported by the National Science Council of Taiwan under grant NSC 922119-M-002-006 with TEC Contribution Number 00007.

\section{REFERENCES}

Ando, S., 1930: On the geology of the Byoritsu oil-field in Taiwan. J. Geol. Soc. Tokyo, 37, 799-803.

Caine, J. S., J. P. Evans, and C. B. Foster, 1996: Fault zone architecture and permeability structure. Geology, 24, 1025-1028.

Chang, S. L., 1971: Subsurface geologic study of the Taichung basin. Petrol. Geol. Taiwan, 8, 21-45.

Chen, W. S., Y. G. Chen, R. C. Shih, T. K. Liu, N. W. Huang, C. C. Lin, S. H. Sung, and K. J. Lee, 2003: Thrust-related river terrace development in relation to the 1999 Chi-Chi earthquake rupture, Western Foothills, central Taiwan. J. Asian Earth Sci., 21, 473480.

Chester, F. M., and J. M. Logan, 1986: Composite planar fabric of gouge from the Punchbowl fault, California. J. Struct. Geol., 9, 621-634.

Chester, F. M., and J. S. Chester, 1998: Ultracataclasite structure and friction processes of the San Andreas fault. Tectonophysics, 295, 199-221. 
Chi, W. R., and H. M. Huang, 1981: Nannobiostratigraphy and paleoenvironments of the late Neogene sediments and their tectonic implications in the Miaoli area, Taiwan. Petrol. Geol. Taiwan, 18, 111-129.

Chou, J. T., 1977: Sedimentology and paleogeography of the Pleistocene Toukoshan Formation in western Taiwan. Petrol. Geol. Taiwan, 14, 25-36.

Covey, M., 1984: Lithofacies analysis and basin reconstruction, Plio-Pleistocene western Taiwan foredeep. Petrol. Geol. Taiwan, 20, 53-83.

Foster, C. B., and J. P. Evans, 1991: Hydrogeology of thrust faults and crystalline thrust sheets: results of combined field and modeling studies. Geophy. Res. Lett., 18, 979-982.

Ho, C. S., 1986: An introduction to the Geology of Taiwan: Explanatory Text of the Geologic Map of Taiwan, Cent. Geol. Survey, Taiwan, ROC, 163 pp.

Ho, H. C., and M. M. Chen, 2000: Taichung-Explanation Text of the Geological Map of Taiwan 24, 65 pp.

Hung, J. H., and D. V. Wiltschko, 1993: Structure and kinematics of arcuate thrust faults in the Miaoli-Cholan area of western Taiwan. Petrol. Geol. Taiwan, 28, 59-96.

Hung, J. H., and J. Suppe, 2000: Subsurface geometry of the Chelungpu fault and surface deformation style. Inter. Workshop Ann. Commun. Chi-Chi Earthquake, 1, 133-144.

Hung, J. H., Y. H. Wu, and E. C. Yeh, 2005: Characteristics of fault zone from cores and geophysical logs in the Wells of Taiwan Chelungpu Fault Drilling Project, west-central Taiwan. Abstract of Annual Meeting of Geological Society Loacted in Taipei, 26.

Johnson, S., Y. J. Hsu, P. Segall, and S. B. Yu, 2001: Fault geometry and slip distribution of the 1999 Chi-Chi, Taiwan earthquake imaged from inversion of GPS data. Geophy. Res. Lett., 28, 2285-2288.

Kanamori, H., D. L. Anderson, and T. H. Heaton, 1998: Frictional melting during faulting. Science, 279, 839-842.

Kanamori, H., and T. H. Heaton, 2000: Microscopic and macroscopic physics of earthquakes. In: Rundle, J. B., D. L. Turcotte, and W. Klein (Eds.), Geocomplexity and the Physics of Earthquakes, AGU, Washington, D. C., 147-163.

Kao, H., and W. P. Chen, 2000: The Chi-Chi earthquake sequence: active out-of-sequence thrust faulting in Taiwan. Science, 288, 2346-2349.

Kuo, L. W., and S. R. Song, 2005: Characteristics of clay mineralogy in the fault zone of the TCDP and its implication, abstract of the Annual Meeting of the Geological Society located in Taipei, $45 \mathrm{pp}$.

Lee, J. F., 1994: Sanyi fault and their neotectonic significance. Ti-Chih, 14, 73-96.

Lee, J. F., 2000: Tungshih-Explanation Text of the Geological Map of Taiwan 18, 117 pp.

Lin, A., T. Shimamoto, T. Maruyama, S. Motoko, T. Miyata, K. Takemura, H. Tanaka, S. Uda, and A. Murata, 2001: Comparative study of cataclastic rocks from a drill core and outcrops of the Nojima fault zone on Awaji island, Japan. The Island Arc, 10, 368-380.

Ma, K. F., C. T. Lee, Y. B. Tsai, T. C. Shin, and J. Mori, 1999: The Chi-Chi Taiwan earthquake: large surface displacement on an island thrust fault. EOS, 80, 605-611.

Ma, K. F., E. E. Brodsky, J. Mori, C. Ji, T. R. A. Song, and H. Kanamori, 2003: Evidence for fault lubrication during the 1999 Chi-Chi, Taiwan, earthquake ( $\mathbf{M}_{\mathrm{w}}$ 7.6). Geophys. Res. Lett., 30, 1244, doi: 10.1029/2002GL015380. 
Magloughlin, J. F., and J. G. Spray, 1992: Frictional melting processes and products in geological materials: Introduction and discussion. Tectonophysics, 204, 197-204.

Meng, C. Y., 1963: San-I overthrust. Petrol. Geol. Taiwan, 2, 1-20.

Pathier, E., B. Fruneau, B. Deffontaines, J. Angelier, C. P. Chang, S. B. Yu, and C. T. Lee, 2003: Coseismic displacements of the footwall of the Chelungpu fault by the 1999, Taiwan, Chi-Chi earthquake from InSAR and GPS data. Earth Planet. Sci. Lett., 212, 73-88.

Scholz, C. H, and M. H. Anders, 1994: The permeability of faults in the mechanical involvement of fluids in faulting. US Geol. Sur. Open-File Report, 94-228, 247-253.

Seno, T., and S. Maruyama, 1984: Paleogeographic reconstruction and origin of the Philippine Sea. Tectonophysics, 102, 53-84.

Sibson, R. H., 1975: Generation of pseudotachylyte by ancient seismic faulting. Geophy. J. R. Astrono. Soc., 43, 775-794.

Sibson, R. H., 1977: Fault rocks and fault mechanisms. J. Geol. Soc. London, 133, 191-213.

Suppe, J., 1981: Mechanics of mountain-building and metamorphism in Taiwan. Mem. Geol. Soc. China, 4, 67-89.

Teng, L. S., 1987: Stratigraphic records of the late Cenozoic Penglai Orogeny of Taiwan. Acta Geol. Taiwan., 25, 205-224.

Teng, L. S. 1990: Geotectonic evolution of late Cenozoic arc-continent collision in Taiwan. Tectonophysics, 183, 57-76.

Theunissen, K., L. Smirnova, and B. Dehandschutter, 2002: Pseudotachylytes in the southern border fault of the Cenozoic intra-continental Teletsk basin (Altai, Russia). Tectonophysics, 351, 169-180.

Toyoshima, T., M. Komatsu, and T. Shimura, 1994: Tectonic evolution of lower crustal rocks in an exposed magmatic arc section in the Hidaka metamorphic belt, Hokkaido, northern Japan. Isl. Arc, 3, 182-198.

Tsai, Y. B., Z. S. Liaw, T. Q. Lee, M. T. Lin, and Y. H. Yeh, 1981: Seismological evidence of an active plate boundary in the Taiwan area. Mem. Geol. Soc. China, 4, 143-154.

Wang, C. Y., C. L. Lee, M. C. Wu, and M. L. Ger, 2007: Investigating the TCDP drill site using deep and shallow reflection seismics. Terr. Atmos. Ocean. Sci., 18, 129-141, doi: 10.3319/TAO.2007.18.2.129(TCDP).

Wilson, B., T. Dewers, Z. Reches, and J. Brune, 2005: Particle size and energetics of gouge from earthquake rupture zones. Nature, 434, 749-752.

Wu, J. C., S. T. Huang, M. H. Wang, C. C. Tsai, W. W. Mei, J. H. Hung, T. Y. Lee, K. M. Yang, and K. F. Lee, 2007: Core slabbing and nannofossil analysis on the Chelungpu fault zone, Taichung, Taiwan. Terr. Atmos. Ocean. Sci., 18, 295-325, doi: 10.3319/ TAO.2007.18.2.295(TCDP).

Yang, T. F., Y. C. Liang, C. C. Chang, C. C. Wang, S. R. Song, and C. Y. Wang, 2005: Compositions of on-site monitoring on dissolved gas of drilling mud flow and poregases of drilled cores of TCDP. Abstract of Annual Meeting of Geological Society Loacted in Taipei, 56.

Yeh, E. C., H. Sone, T. Nakaya, K. H. Ian, S. R. Song, J. H. Hung, W. Lin, T. Hirono, C. Y. Wang, K. F. Ma, W. Soh, and M. Kinoshita, 2007: Core description and characteristics 
of fault zones from Hole-A of the Taiwan Chelungpu-fault Drilling Project. Terr. Atmos. Ocean. Sci., 18, 327-357, doi: 10.3319/TAO.2007.18.2.327(TCDP).

Yu, S. B., and H. Y. Chen, 1994: Global positioning system measurement of crustal deformation in the Taiwan arc-continent collision zone. Terr. Atmos. Ocean. Sci., 5, 477-498.

Yu, S. B., H. Y. Chen, and L. C. Kuo, 1997: Velocity fields of GPS stations in the Taiwan area. Tectonophysics, 274, 41-59.

Yu, S. B., L. C. Kuo, R. S. Punongbayan, and E. G. Ramos, 1999: GPS observations of crystal deformation in the Taiwan-Luzon region. Geophys. Res. Lett., 26, 923-926.

Yu, S. B., Y. J. Hsu, L. C. Kuo, H. Y. Chen, and C. C. Liu, 2003: GPS measurement of postseismic deformation following the 1999 Chi-Chi, Taiwan, earthquake. J. Geophys. Res., 108, 2520, doi: 10.1029/2003JB002396.

Song, S. R., L. W. Kuo, E. C. Yeh, C. Y. Wang, J. H. Hung, and K. F. Ma, 2007: Characteristics of the lithology, fault-related rocks and fault zone structures in TCDP Hole-A. Terr. Atmos. Ocean. Sci., 18, 243-269, doi: 10.3319/TAO.2007.18.2.243(TCDP). 